\title{
A expulsão do artista na República de Platão e a expulsão de Adão e Eva no Gênesis Judaico
}

\author{
Luciano Coutinho* \\ Caroline Albergaria**
}

\section{Resumo}

Este artigo discorrerá sobre semelhanças e diferenças nas expulsões do artista na República de Platão e da humanidade do Paraíso no Gênesis. 1) No início da República, Sócrates, tirânico, expulsa o artista da polis, pois avalia que a arte torna-se uma arma manipulatória das psychai, quando entendida literalmente; porém, ao final do diálogo, Sócrates, já filósofo, sustenta que a cegueira religiosa que torna representações artísticas em verdades é que deveria ser expulsa. 2) No Gênesis, Deus, tirânico, expulsa Adão e Eva do Paraíso, por provarem do fruto da árvore do conhecimento que os tornaria menos ignorantes. Assim, o 'conhecimento' e sua falta (a ignorância) serão nosso foco de análise, já que assumem princípios fundantes da própria humanidade nas duas imagens. Palavras-chave: Expulsão. República platônica. Gênesis judaico. Conhecimento.

* Universidade de Brasília, Faculdade de Arquitetura e Urbanismo (PPG-FAU/UnB). Instituto Federal da Paraíba (IFPB).Licenciado em Letras Português/Espanhol e Licenciado em Filosofia. Doutor em Estudos Clássicos / Filosofia pela Universidade de Coimbra (com bolsa CAPES para Doutorado Pleno no Exterior). Tem dois Pós-Doutorados em Filosofia pela Universidade Federal de Uberlândia (um deles com bolsa CAPES). Professor da linha de pesquisa "Estética, Hermenêutica e Semiótica" do Programa de Pós Graduação da Faculdade de Arquitetura e Urbanismo da Universidade de Brasília (PPG-FAU/UnB) e Professor de Filosofia do Instituto Federal da Paraíba (IFPB). Email: lucianocoutinho1@, gmail.com. Currículo Lattes: http://lattes.cnpq.br/4627115906284290

** https://orcid.org/0000-0001-5521-7168. Universidade de Brasília, Faculdade de Arquitetura e Urbanismo (PPG-FAU/UnB). Arquiteta e Urbanista formada pela Faculdade de Arquitetura e Urbanismo da Universidade de Brasília (FAU/UnB). Mestranda do Programa de Pós-Graduação da Faculdade de Arquitetura e Urbanismo da Universidade de Brasília (PPG-FAU/UnB) na linha de pesquisa "Estética, Hermenêutica e Semiótica". Email: carol. albergaria6@gmail.com. Currículo Lattes: http://lattes.cnpq.br/7984398923643506 


\title{
The expulsion of the artist in plato's Republic and the expulsion of Adam and Eve in the Jewish Genesis
}

\begin{abstract}
In this article, we will discuss similarities and differences in the expulsion of the artist in Plato's Republic and in that of Adam and Eve from Paradise in the Genesis. 1) At the beginning of the Republic, Socrates, in his tyrannical posture, expels the artist from the polis, as he considers art to become a manipulative weapon of the psychai when understood literally; as a philosopher at the end of the dialogue, however, Socrates claims that it is the religious blindness, which turns artistic representations into truths, that should be expelled. 2) In the Genesis, God, in his tyrannical posture, expels Adam and Eve from Paradise, as they tasted the fruit of the tree of knowledge, which would render them less ignorant. Thus, 'knowledge' and the lack of it (ignorance) will be the focus of our analysis, since they assume fundamental principles of humanity itself in the two images.
\end{abstract}

Keywords: Expulsion. Plato’s Republic. Jewish Genesis. Knowledge.

\section{La expulsión del artista en la República de Platón y la expulsión de Adán y Eva en el Génesis Judío}

\section{Resumen}

Este artículo discutirá similitudes y diferencias de las expulsiones del artista en la República de Platón y de la humanidad del Paraíso en el Génesis. 1) En el inicio de la República, Sócrates, tiránico, expulsa el artista de la polis, pues cree que el arte se convierte en un arma manipulativa de las psychai, cuando compreendida como verdad; sin embargo, como filósofo, al final del diálogo, Sócrates sostiene que la ceguera religiosa es la que debería ser expulsada, ya que convierte las representaciones artísticas en verdades incuestionables. 2) En el Génesis, Dios, como un tirano, expulsa Adán y Eva del Paraíso, por desobedecer su ley y probar el fruto del conocimiento que los hace menos ignorantes. Así, el 'conocimiento' y su carencia (la ignorancia) serán nuestro foco de análisis, ya que asumen principios fundamentales de la humanidad misma en las dos imágenes.

Palabras clave: Expulsión. República platónica. Génesis judío. Conocimiento.

\section{Introdução}

Na República de Platão, o primeiro Sócrates, com uma postura tirânica, expulsa o artista da polis. No Gênesis, Deus expulsa Adão e Eva do Paraíso. Este é foco com o qual iremos confrontar a temática do conhecimento ao longo deste artigo.

Na República, o primeiro Sócrates, aquele que baseado em pressupostos bastante tirânicos, expulsa o artista da polis, passa a representar o excesso do próprio Estado, que, em vez de proteger seus cidadãos, utiliza as histórias 
criadas pelos artistas para manipular as psychai dos habitantes da cidade. É nessa atmosfera que ele propõe a expulsão do grande artista e a manipulação do artista menor, para, com sua ajuda, manipular os cidadãos.

No Gênesis, o casal criado por Deus desobedece às leis divinas e se apropria do fruto da árvore do conhecimento do bem e do mal, tornando-se menos puros, mas também menos ignorantes. É baseado nessa desobediência desse fruto proibido que Deus expulsa o ser humano do Paraíso.

Até aí os textos parecem abrigar um princípio de tirania semelhante. Mas o fato é que o Sócrates personagem se transforma a partir do livro sexto e, como um filósofo, descobre que um Estado justo não é feito de manipulações de fora para dentro, mas antes de compreensão interior, de dentro para fora. Nesse sentido, o Sócrates filósofo da segunda parte da República sugere não mais a expulsão do artista, mas antes a expulsão da ignorância dos cidadãos que entendem o artista e a arte como detentores da verdade divina.

Fica clara, aí, a oposição da importância de se adquirir conhecimento na República e no Gênesis. Na República, a expulsão do grande artista é proposta por Sócrates (o primeiro) como método de manutenção da ignorância, propondo também que se vigie e manipule a produção dos pseudo-artistas, para depois, em sua evolução filosófica na trama dialógica, o próprio Sócrates (o segundo) percebe que o Estado não pode manipular seus cidadãos de fora para dentro, isto causaria uma pseudo-cidade-justa, com isso, o que era visto como um perigo, o artista, passa a ser visto como aliado para a educação em prol de uma cidade realmente justa, expulsando não o artista ao final da República, mas antes a ignorância de se acreditar em imagens poéticas como verdades absolutas. No Gênesis, por outro lado, Deus expulsa o ser humano exatamente pelo motivo oposto: por adquirir conhecimento, que, ao que parece, deveria ficar apenas sob a ordem da ignorância.

Dito de outra maneira, o que é bom e justo para o Sócrates da República é o conhecimento humano, dado de dentro para fora, a partir de muita reflexão, enquanto o bom e justo para Deus é a ignorância, imposta de fora para dentro, a partir da obediência irreflexiva.

\section{A expulsão do artista na República}

A República, de Platão, tem como tema principal a concepção de uma polis ideal, porém o leitor atento irá perceber, ao longo dos dez livros, que se trata, na verdade, da psyche ideal dos indivíduos pertencentes à polis, 
principalmente de seus governantes, que "são os mais valiosos"1 cidadãos. Sócrates é o incumbido de apresentar as virtudes principais, além de listar os vícios e as fraquezas que corrompem os homens e as mulheres da polis. Ao listá-los, Sócrates, nos livros iniciais, apresenta-se como um tirano ${ }^{2}$.

O livro segundo abriga uma das mais populares tiranias de Sócrates: a expulsão do artista da polis ${ }^{3}$, na verdade a dos grandes poetas ${ }^{4}$. Em algumas passagens do livro segundo, que parecem dificultar sua compreensão ${ }^{5}$, Sócrates elogia as poesias de Homero: "Ora nós, que elogiamos muita coisa em Homero, não louvaremos uma, que é o envio do sonho por Zeus a Agamémnon" (PLATÃO, Rep. II, 383a). De maneira proposital, o elogio é seguido, todavia, de uma postura opressiva quanto à tradição divinatória, já que Sócrates percebe que, para o povo, essa vidência da nobreza acaba por se tornar uma verdade divina e não uma imagem poética como seria suposto.

Homero escreveu, na Ilíada, a trajetória de Agamênon no comando do exército dos aqueus. O poema descreve que um mensageiro de Zeus enviou instruções a Agamênom por meio de um sonho para atacar Troia. Sócrates acredita ser um problema o trecho, pois o comandante estaria justificando suas estratégias por meio de um sonho.

"Tu dormes, ó filho do fogoso Atreu, domador de cavalos.

Não deve dormir toda a noite o homem aconselhado,

a quem está confiada a hoste, a quem tantas coisas preocupam.

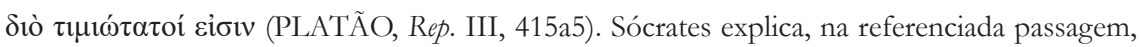
que os cidadãos aptos a governarem tiveram ouro misturado em sua composição e, por isso, são os mais valiosos para a polis.

2 Curado explica que as ideias platônicas foram questionadas pela primeira vez na primeira metade do século XX devido ao cenário da política mundial. O comentador português afirma que os diálogos de Platão, como a República e as Leis, defendiam a ideia "de um Estado que tudo pode", inspirando os governos totalitários que vieram à tona no início do século XX (CURADO, 2017, p. 189-190). É importante reafirmar que a transição do Sócrates tirano para o Sócrates iniciado em Filosofia é retratada de maneira gradual e dramática na República, e isto não pode ser percebido nas regras impostas na primeira metade do diálogo. Platão não escreve tratados, e Coutinho descreve esse melhoramento psíquico no drama em "O drama de Katabasis na República de Platão: considerações em

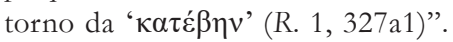

3 Cf. PLATÃO, Rep. II, 383a-c e PLATÃO, Rep. II, 387b-c.

4 Platão exemplifica a questão utilizando o grande poeta Homero, porém entendemos que o filósofo abrange, aí, todos os grandes artistas.

5 Coutinho explica que Sócrates passa por momentos contraditórios como este no decorrer da República, a fim de representar sua "caminhada filosófica rumo ao melhoramento da psyche humana, e, consequentemente, da polis" (COUTINHO, 2017b, p. 134). 
Mas agora presta rapidamente atenção. Sou mensageiro de Zeus, que embora esteja longe tem grande pena e se compadece de ti.

Manda armar depressa os Aqueus de longos cabelos, pois agora te seria dado tomar a cidade de amplas ruas dos Troianos, porquanto se não dividem já os imortais que no Olimpo têm a sua morada (a todos convenceu Hera suplicante), mas sobre os Troianos pousam desgraças vindas de Zeus. Mas tu guarda isto no teu espírito; que o olvido se não apodere de ti, quando te largar o sono doce como mel." (Hom. Il. 2, v. 23-34)

Os poemas homéricos e hesiódicos tinham caráter religioso. O problema disso, para Platão, é que os indivíduos tomavam importantes decisões na polis justificadas por revelações divinas em sonhos, previsões, oráculos, dentre outros. Logo, no ímpeto do primeiro momento, Sócrates acredita que, para não viverem em um tipo de ignorância oficial, o grande artista, mais especificamente o grande poeta, deveria ser expulso da polis, sugerindo, assim, apenas a continuidade daqueles fazedores de mytho $i^{6}$ que podem ser manipulados pelo Estado:

- Logo, devemos começar por vigiar os autores de fábulas, e seleccionar as que forem boas, e proscrever as más. As que forem escolhidas, persuadiremos as amas e as mães e contá-las às crianças, e a moldar as suas almas por meio das fábulas, com muito mais cuidado do que os corpos com as mãos. Das que agora se contam, a maioria deve rejeitar-se (PLATÃO, Rep. II, 377b-c).

Como consequência, os governantes são denunciados como aqueles que se utilizam dos mythoi, especialmente os grandes mythoi como os artísticos, para ludibriar os indivíduos no interior da polis.

Platão percebe que o grande mythos tem uma imensa capacidade de sintonizarse com a psyche humana; e este é o princípio que o Estado utiliza para manter as psychai em profunda ignorância. Isto ocorre quando um mythos é entendido como revelação religiosa e não como verossimilhança representativa a questões profundas da psyche humana. Nesse sentido, aquilo que poderia proporcionar (auto)conhecimento acaba por proporcionar ignorância. Ou seja, se entendido

A expressão utilizada é realmente mythos (mythoi no plural), mas, no contexto, podemos entender que Platão se refere ao mythos artístico ou à "arte"; afinal, a palavra mythos, para o grego antigo, além de "mito" significa também "mentira", "discurso público", dentre outras coisas (Cf. COUTINHO, 2017a, p. 114 e 119). 
como verossimilhança representativa, um mythos pode levar as psychai para um grau de (auto)conhecimento elevado, mas, se entendido como revelação religiosa, pode levá-las a mais completa cegueira. É com essa descoberta que a personagem Sócrates defende, no livro segundo, a ideia de que o Estado deveria vigiar os fazedores de mythos e proibir a circulação dos mythoi de grande impacto psíquico, para evitar que as psychai, em suas ignorâncias, entendam os mythoi de maneira literal e acreditem em suas imagens de superfícies como se fossem verdades reveladas (COUTINHO, 2017a, p. 117).

Esse tipo de manipulação dá-se por gerações e acaba por se tornar um tipo de "verdade", basta observarmos o diálogo em que Sócrates relata a criação do mythos de autoctonia (acerca da formação das psychai com ouro, prata e/ou bronze/ferro). Ao final, Sócrates indaga se existe algum meio de persuadir quem escutou esse mythos. Nele, Glauco explica que as gerações vindouras dar-lhe-ão crédito como se fosse uma verdade:

- É muito natural - respondi -. Ouve, no entanto, o resto do mito. "Vós sois efectivamente todos irmãos nesta cidade" - como diremos ao contar-lhes a história - "mas o deus que vos modelou, àqueles dentre vós que eram aptos para governar, misturou-lhes ouro na sua composição, motivo por que são mais preciosos; aos auxiliares, prata; ferro e bronze aos lavradores e demais artífices". (...) Sabes de algum expediente para fazer acreditar neste mito?

- Nenhum, para que esses homens creiam nele; mas talvez para os filhos deles, para os que vierem após eles, e os demais homens (PLATÃO, Rep. 415a-d).

Analisemos a postura de Sócrates diante da situação. Sócrates percebe que há um grande problema enfrentado na polis: os indivíduos creem que a poesia é um relato de verdades. Sócrates tem a percepção geral do problema, porém, aí no livro segundo, não toma a decisão correta para resolvê-lo. Como tirano, propõe uma solução tirânica: a expulsão do artista.

Se levarmos a imagem a sério, as consequências dessa ação seriam terríveis. Dentre elas, podemos citar:

um tipo de fechamento mental radical da polis, em que as interrelações com outros povos poderia ser apenas formal, já que, para as psychai dessa polis fechada, a verdade só pode ser encontrada no interior de sua polis, podendo ser exilada qualquer psyche que pense ou que pratique algo diferente; a manutenção do sistema de poder, que seria apenas trocado de mãos, antes políticos, agora pseudo-filósofos; 
o castigo brutal aos indivíduos que passariam apenas a usufruir da arte suas limitadas imagens de superfície, sem nunca poder desfrutar da profundidade estética de uma grande obra de arte;

e, talvez, a pior das consequências, a manutenção da ignorância dos indivíduos, já que o Estado não os orientaria para uma formação dialética de dentro da psyche para fora, mas, ao contrário, de fora para dentro, em que algumas mentiras são escondidas enquanto outras são alimentadas e criadas.

Esse Sócrates representa o tipo de governo que julga ser certa a limitação do conhecimento aos indivíduos, no intuito de protegê-los de suas próprias ignorâncias, dando-lhes acesso apenas àquilo que julga não ser maléfico à condição de ignorância em que vivem. A consequência disto é a polis sob o domínio da tirania de pensamento.

As leis são punitivas e impostas à população, que não possui intelecção suficiente para compreender o problema e contestar as leis vigentes. Sócrates, no intuito de punir apenas os artistas, na realidade, pune os três sujeitos envolvidos: o Estado, por se fechar; os cidadãos, por serem mantidos em sua ignorância; o artista, por ser exilado. A punição deste último sujeito leva ao ciclo da punição dos três, já que este é o ofício que busca tocar a psyche humana de dentro para fora; em outras palavras, uma chance real de educar os indivíduos, se não forem utilizados para fins políticos de sistemas de poder.

Mais a frente, o problema da expulsão é retomado por Sócrates, porém pós teoria da Linha, trecho mais importante do diálogo para a compreensão do problema da verdade/mentira nas percepções da psyche humana, que posteriormente é exemplificada pela famosa alegoria da Caverna ${ }^{7}$. Com essas imagens, notamos a mudança de postura de Sócrates, que passa a refletir a polis como um filósofo, não mais como um tirano pseudo-filósofo. A alegoria da Caverna nos ensina que é necessário sairmos das sombras e buscarmos os níveis seguintes para nos aproximarmos da luz, ou seja, das verdades. Diferentemente do Sócrates tirânico, que impõe um melhoramento da polis e da psyche humana de fora para dentro, a teoria da Linha e a alegoria da Caverna consideram o melhoramento da psyche e, consequentemente, da polis um exercício que se dá de dentro para fora.

Sobre a imagem da Linha e a alegoria da Caverna, cf. Platão, Rep. VI, 509d-Rep. VII, 518d. Platão abordou sobre os níveis de intelecção na famosa imagem da Linha, que é seccionada em quatro partes desiguais, cada uma representando um nível de conhecimento: o quarto nível, o mais elevado, não é possível ser vislumbrado em completude pela psyche humana, pois não possuímos gênesis intelectiva para isso. 
É depois dessa mudança de postura, que o regulamento da poesia é retomado no Livro décimo, quando Sócrates supõe que, se a cidade imaginada por ele for a mais justa, deve-se optar por não aceitar as poesias com princípios "miméticos", pois "afiguram ser a destruição da inteligência dos ouvintes, de quantos não tiverem como antídoto o conhecimento da sua verdadeira natureza” (PLATÃO, Rep. X, 595b).

A percepção do juiz é completamente mudada, já que passa a entender que o problema não é a poesia em si, mas sim a falta de conhecimento dos indivíduos para distinguirem seu caráter artístico de um alegado caráter religioso.

Porém, o Estado deveria solucionar o erro desde a essência, ou seja, deveria capacitar os indivíduos sobre o desígnio do artista, em vez de expulsálo, conforme o Sócrates tirânico propõe anteriormente. Dessa maneira, o ofício dos poetas e de todos os outros artistas não seriam renegados na polis, pelo contrário, poderia ser melhor utilizado para tocar a psyche humana, não como uma verdade religiosa, mas como uma verdadeira ampliação da própria percepção psíquica. Sócrates acredita no melhoramento do indivíduo, caso este tenha uma psyche com conhecimento, capaz de tirar proveito do que é mimético. Exemplo disso é a conclusão de Sócrates após o relato do mythos de Er no livro décimo. Esse mythos explica sobre a imortalidade da alma e a passagem das almas pelo Hades. O mythos de Er instrui sobre os valores da justiça, da sabedoria e da felicidade?.

Foi assim, ó Gláucon, que a história se salvou e não pereceu. E poderá salvarnos, se lhe dermos crédito, e fazer-nos passar a salvo o rio do Letes ${ }^{10}$ e não poluir a alma. Se acreditarem em mim, crendo que a alma é imortal e capaz de suportar todos os males e todos os bens, seguiremos sempre o caminho para o alto, e praticaremos por todas as formas a justiça com sabedoria, a fim de sermos caros a nós mesmos e aos deuses, enquanto permaneceremos

8 A expressão é $\mu$ ıптıкоúc (mimetikous), que significa "hábeis a imitar".

9 O relato de Er é o último mythos da República; cf. PLATÃO. Rep. X, 614b-621d. É por meio dele que Sócrates conclui que o destino de cada cidadão é unicamente condicionado por suas ações. Coutinho explica que o intuito do mythos é "(re)condicionar a atitude da psyche humana como agente ativo de seu próprio destino" (COUTINHO, 2015, p. 130). Um ponto importante acerca dos mythoi é que: possivelmente Platão opta por finalizar a República com um importante mythos, para reforçar a importância dos mythoi como possíveis auxiliadores no processo de melhoramento das psychai. Ao contrário do Sócrates tirânico que não percebe o valor estético dos mythoi e os utiliza para manipular, o Sócrates filósofo utiliza-os para tentar educar.

10 O nome do rio no Hades é $\Lambda \dot{\eta} \theta \eta$ (Lethe) e deriva do adjetivo $\lambda \eta \theta$ aíoc, que significa "o que faz esquecer". 
aqui; e, depois de termos ganho os prêmios da justiça, como os vencedores dos jogos que andam em volta a recolher as prendas da multidão, tanto aqui como na viagem de mil anos que descrevemos, havemos de ser felizes (PLATÃO, Rep. X, 621b-d).

No livro sétimo, Sócrates apresenta a alegoria da Caverna e explica que "alguém" solta um dos prisioneiros das correntes que o prendiam. Esse "alguém" o força a olhar para luz e buscar a verdade. Podemos chamar esse "alguém" de "filósofo", responsável por auxiliar na busca da verdade, mesmo quando nos é mais vantajoso permanecer nas sombras. A maior função do filósofo na polis, nesse sentido, não seria propriamente governar em sentido político, mas antes em sentido psicológico, cuja intenção maior é educar as psychai dos indivíduos. Para isto, nenhum benefício político deve ser almejado pelo filósofo governante.

É, aliás, em uma das alegorias mais famosas da História da Filosofia que Platão nos apresenta uma figura fundamental para o contexto do diálogo, talvez o único da República que age segundo esse "bom": o alguém ( $\tau \iota \varsigma$ ) que solta o prisioneiro no interior da Caverna. Este alguém assume, na alegoria, o papel de um filósofo, que, sem pretender recompensas pessoais, age quase que invisivelmente ao praticar uma boa ação (COUTINHO, 2017a, p. 121).

Sócrates compreende que o Estado deveria garantir o bem dos cidadãos e, consequentemente, deveria tirá-los da ignorância, assim os mythoi não seriam entendidos como verdade, mas como mythoi, ou no contexto específico que Platão nos coloca, como arte. É de fundamental importância que o Estado direcione as psychai para que possam melhorar suas percepções da realidade ${ }^{12}$. Para isto, o Estado deve proporcionar uma educação que proporcione a seus cidadãos a capacidade de perceber que, na arte, há elementos metafóricos e alegóricos que tornam invisíveis outros aspectos psíquicos mais verossímeis e mais importantes para a própria psyche. Assim, de maneira similar à alegoria da Caverna, o Estado seria o "alguém" que assumiria o papel de libertar a polis acorrentada.

$11 \tau \iota \varsigma$ (PLATÃO, Rep. VII, 515c6).

12 Cornelli, em seu artigo "Aquele que ama o mito é, de alguma forma, filósofo: Algumas considerações sobre a necessidade do mito para a filosofia", discorre sobre a relação entre o mythos e o logos e afirma que ambos "são indispensáveis para chegar a verdade" (CORNELLI, 2003, p. 115). 
O tema da invisibilidade também é retratado no mythos de Giges ${ }^{13}$ no livro segundo da República, em que Glauco expõe sobre a natureza e a origem da justiça. Esse mythos apresenta um anel com o poder de tornar o soma de quem o usa invisível, este "anel da invisibilidade é o elemento mítico que tornaria visível a psyche humana” (COUTINHO, 2018, p. 851) e evidenciaria se o indivíduo é justo ou injusto. O filósofo que liberta o prisioneiro da caverna é justo, mesmo quando seu soma está invisível, pois ele acredita que tirar o prisioneiro de sua condição de ignorância é o melhor a se fazer, mesmo quando não há testemunhas para recompensá-1o ${ }^{14}$ politicamente.

Se recontextualizarmos esse problema da invisibilidade com a questão do caráter mimético da poesia, veremos que Platão sustenta que, impossibilitados de ver o que há de mais verossímil na arte, por causa da ignorância, os indivíduos em geral entendem a mímesis (os traços de superfície da obra artística, ou suas metáforas e alegorias) como verdades absolutas, divinizadas por seus fazedores. Nesse sentido, acreditar na mímesis como verdade é acreditar em uma parcela apenas da verdade como, por exemplo, acreditar na sombra que é uma parte muito pequena da realidade, muito distante daquilo que ela imita.

Por conseguinte, a arte de imitar está bem longe da verdade, e se executa tudo, ao que parece, é pelo facto de atingir apenas uma pequena porção de cada coisa, que não passa de uma aparição. Por exemplo, dizemos que o pintor nos pintará um sapateiro, um carpinteiro, e os demais artífices, sem nada conhecer dos respectivos ofícios. Mas nem por isso deixará de ludibriar as crianças e os homens ignorantes, se for bom pintor, desenhando um carpinteiro e mostrando-o de longe com a semelhança, que lhe imprimiu, de um autêntico carpinteiro (PLATÃO, Rep. X, 598b-598c).

Sócrates compreende que tratar a poesia como "verdade" é prejudicial à psyche humana e, consequentemente, à polis. Porém, no final da República, já um iniciado em filosofia, ele não expulsa os grandes artistas, ou mais especificamente os grandes poetas, mas busca chamar a atenção acerca do perigo que é assumir uma imagem mimética como verdadeira. Assim, ele chama a atenção também para o valor estético da poesia, que não pode se confundir com a apresentação de uma verdade religiosa.

13 Cf. PLATÃO, Rep. II, 358e-361d.

14 Para entender melhor a relação entre o "alguém” e o mythos do anel de Giges, cf. COUTINHO, 2018, p. 859-862. Para entender o processo de katabasis do antepassado de Giges, cf. COUTINHO, 2017b, p. 128-130. 
A maneira como Sócrates diz que as pessoas que louvam as poesias homéricas devem ser tratadas no livro décimo é um importante sinal para entendermos a própria mudança de pensamento da personagem em relação à poesia:

Por conseguinte, ó Glauco, quando encontrares encomiastas de Homero, a dizerem que esse poeta foi o educador da Grécia, e que é digno de se tomar por modelo no que toca a administração e a educação humana, para aprender com ele a regular toda a nossa vida, deves beijá-los e saudá-los como sendo as melhores pessoas que é possível, e concorda com eles em que Homero é o maior dos poetas e o primeiro dos tragediógrafos, mas reconhece que, quanto a poesia, somente se devem receber na cidade hinos aos deuses e encómios aos varões honestos e nada mais. Se, porém, acolheres a Musa aprazível na lírica ou na epopéia, governarão a tua cidade o prazer e a dor, em lugar da lei e do princípio que a comunidade considere, em todas as circunstâncias, o melhor (PLATÃO, Rep. X, 606e-607a).

O discurso de Sócrates, nessas páginas, possui um caráter bastante metafórico e irônico. O Sócrates filósofo reflete, aí, o papel dos mythoi artísticos e do artista na polis, já no último livro da República, demonstrando, em um cenário hipotético, como um governante filósofo deveria reconhecer os grandes mythoi (no caso exemplificado, as poesias homéricas).

Sócrates sugere, nesse sentido, que "quanto a poesia, somente se devem receber na cidade hinos aos deuses e encómios aos varões honestos e nada mais”, Há aí uma profunda ironia por parte de Sócrates, já que ele não acredita nos "deuses" e menos ainda na tradição homérica que se fixou com os "varões honestos". A ironia está no fato de que os deuses homéricos não devem ser entendidos literalmente como verdades; cabe lembrarmo-nos de que, na Apologia, Platão explora o principal motivo que levou Sócrates a ser punido com a morte pelo governo: as acusações de ateísmo e de corrupção dos jovens contra os deuses, das quais "Meleto, em nome dos poetas"15, profere as mais severas.

Havelock está correto ao interpretar o prazer como uma sensação que os espectadores se tornavam dependentes, "pois significava alívio da angústia e lenitivo para a tristeza", e a poesia se tornava "fonte de conhecimento e orientação" (HAVELOCK, 1996, p. 170-171). O comentador afirma que, por isso, para Platão, a poesia é um "veneno psíquico” (HAVELOCK, 1996, p.

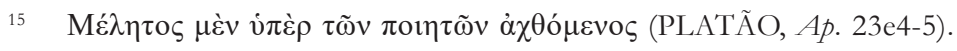


$21)^{16}$. Porém, Havelock reduz o problema ao desprezar as reconciliações que o próprio Sócrates personagem faz com os mythoi (como, por exemplo, o relato de Er) e com os mythoi artísticos (como os poemas homéricos). Assim, quando as psychai acreditam na poesia como verdade religiosa, o que se tem é, de fato, "um perigo moral assim como intelectual" (HAVELOCK, 1996, p. 22), mas se educadas quanto ao caráter estético da poesia, as psychai são capazes de sentir o prazer e a dor em sua representatividade artística, sem os tornar em uma medida de verdade para a prática política na polis. Apenas desta maneira, a arte não é utilizada pelo Estado para moldar as psychai, pois estas não se permitem a tal efeito.

É assim que, no último trecho da passagem, Sócrates menciona que, com prazer e dor tem-se a substituição das "leis", que os cidadãos da polis imaginária de Sócrates consideram a "melhor". Diante de todas as circunstâncias, Platão enfatiza que aquela é uma sociedade que já buscou o melhoramento das psychai e compreendeu que a verdade é fundamental para o indivíduo e para a polis ${ }^{17}$. Dessa maneira, Sócrates é levado a enfatizar o desígnio dos mythoi: tocar as psychai dos indivíduos da polis e auxiliá-las em seu melhoramento de dentro para fora. Sócrates não repete seu erro no início da caminhada que, como tirano, simplesmente expulsa a arte de sua polis.

Assim, se o indivíduo que age segundo "o Bom"18 consegue enxergar aquilo que é verossímil, a boa atitude em relação à poesia seria ultrapassar sua aparência de superfície. A polis que entende a verossimilhança das coisas não será manipulada, mas entenderá a arte a partir de seu valor estético, poético, e não religioso, evitando, com isso, muitas injustiças, baseadas na crença e na religiosidade.

É muito comum os comentadores de Platão interpretarem-no a partir da postura tirânica de sua personagem Sócrates apresentada nos primeiros

16 A respeito da visão brasileira que segue as ideias de Havelock, cf. Muniz em "Platão contra a arte".

17 Ao longo do diálogo, Sócrates elabora uma analogia entre a polis justa e a psyche do indivíduo, para explicar as características de cada parte da cidade e da psyche. Cf. PLATÃO, Rep. IV, 435a-c. Cornelli aborda sobre a homologia da psyche e a polis e ainda nomeia a alma como "micrópolis" (CORNELLI, 2010, p. 82).

18 Cf. PlatÃO, Rep. VI, 505a2-5. Maria Helena de Rocha Pereira, na tradução da República para o Português, traduz a expressão tò ả $\gamma \alpha \theta$ òv por “o Bem”. Comungamos, no entanto, com a leitura de Vegetti, ao dizer que Platão utiliza a expressão como "un aggettivo neutro sostantivato, esatamente come to kalon, to dikaion e così via (tecnicizzati nel linguaggio dele idee con il sintagma auto to-)" (VEGETTI, 2003, p. 253, nota 1); Cf. também COUTINHO, 2015, p. 190-191, nota 463. 
livros da República, o que estamos a chamar de Sócrates tirano, levando a uma postura também tirânica de interpretação que impõe a expulsão de todos os artistas, em Platão, e não a expulsão da ignorância de uma determinada crença ou religiosidade que sustenta como verdade inquestionável aquilo que é antes representação artística. Visões conservadoras e tradicionais sobre a arte em Platão são limitadas à interpretação da camada mais superficial da personagem Sócrates: a do primeiro Sócrates tirano, que, no diálogo, representa um indivíduo distinto em conhecimento, mas ainda perdido em suas próprias imposições ${ }^{19}$. O diálogo da República deve ser, ao contrário, entendido para além de frases isoladas; deve ser entendida como um todo, como uma evolução dramática ${ }^{20}$. Aqui, corrobora-se com a ideia de que Platão utilizou a personagem Sócrates como um exemplo, ele próprio, do auto-melhoramento psíquico ${ }^{21}$.

O cenário hipotético formulado por esse Sócrates filósofo, ao contrário do Sócrates tirano, não busca esconder o problema, propondo a substituição de uma ignorância por outra, mas, ao contrário, busca entender o problema e

19 Curado, por exemplo, em seu "A eugenia platónica: um ensaio prudencial”, faz suas críticas às ações de Sócrates, baseado apenas no Sócrates tirânico, como se esta personagem não se modificasse ao longo do drama dialógico. Leituras como a de Curado, a de Havelock, a de Muniz, dentre tantos outros, trazem, de fato, importantes questionamentos em torno da postura e da forma de composição do próprio filósofo ateniense, mas tendem a reduzir Platão à sua personagem Sócrates em qualquer parte do diálogo. Outro ponto a ser ressaltado é que Curado, mesmo concluindo que as ideias platônicas não são precisamente seguras, explica a teoria platônica a partir da comparação com um diamante: a intenção é argumentar que mesmo sendo uma pedra preciosa, de material mais duro, ainda pode ser quebrado com uma pancada vinda de um ângulo certo, sugere o comentador (cf. CURADO, 2007, p. 194). Em outros momentos, o comentador abre a possibilidade de que Platão esteja certo, mas desiste da possibilidade ao concluir que seria um "resultado obviamente dramático" (CURADO, 2007, p. 195). Por outro lado, as leituras de Havelock e de Muniz seguem críticas mais duras e inflexíveis.

20 Cornelli aborda o uso da tragédia dos diálogos platônicos e afirma que "o Platão filósofo e o Platão tragediógrafo coincidem: a filosofia política de Platão é autofágica” (CORNELLI, 2010, p. 82).

21 Coutinho, em "O drama de Katabasis na República de Platão: considerações em torno da

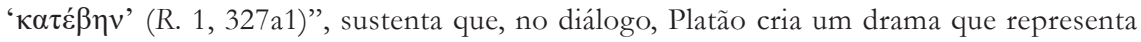
a própria iniciação filosófica da personagem Sócrates, que, nos cinco primeiros livros, é apresentado como um tirano e, nos cinco últimos, é apresentado como um filósofo. Esse processo de iniciação é simbolizado com a imagem de katabasis (descida), um tipo de (auto)mergulho em busca do (auto)conhecimento, e, quanto mais esse mergulho é empreendido, maior é o nível de compreensão, de dentro para fora, da realidade. Isto só pode ser percebido, no entanto, se a personagem for lida no todo dramático da trama dialógica e não se for lido de maneira divorciada em pequenas partes do diálogo. 
sustenta o caminho do conhecimento como a melhor alternativa para superar a ignorância das psychai na polis.

Para o filósofo, a saída das sombras é de fundamental importância a todos os indivíduos, só assim se alcança a verdade. Por conseguinte, o melhor a se fazer é capacitar os cidadãos para que eles possam reconhecer o que é arte, reconhecendo o que, na arte, é metáfora, analogia e verossimilhança. As consequências para esse ajuizamento são:

a não atribuição ao artista o papel de formador da polis; dessa maneira, o exílio só seria destinado àqueles que ainda insistissem em utilizar-se da poesia para a manipulação das psychai dos indivíduos na polis;

a não utilização, por parte do Estado, dos mythoi artísticos para manipular os cidadãos, pois o papel daquele é o de oferecer meios a estes para se capacitarem a ponto de compreenderem que a arte é imagem metafórica, alegórica e verossímil;

a contemplação estética dos mythoi artísticos por parte dos cidadãos, sem confundirem, dessa maneira, valor estético com valor religioso;

a capacidade, por parte dos cidadãos, de perceberem o que é mais ou menos verossímil.

Sócrates, nessa postura filosófica, tem o intuito de educar os indivíduos da polis e, como consequência, acaba por propor leis educativas. Assim, os cidadãos podem elevar o nível de suas psychai, na medida em que elevam suas capacidades de percepção da realidade.

É importante ressaltar que, na República, Platão não coincide com sua personagem Sócrates, pelo menos não em todos os livros do diálogo. Não podemos confundir Sócrates com Platão, nesse sentido, pois o próprio Sócrates, na trama, muda de postura, e o pensamento de Platão é o resultado final de toda a trama e não partes isoladas do todo dialógico ${ }^{22}$. A personagem Sócrates, com isso, é utilizada no diálogo para exemplificar a postura de um governante tirânico e de um governante filósofo diante dos mythoi que circulam na polis. Dessa maneira, Sócrates tem uma empatia maior com o mythos no final da República e se reconcilia com a livre circulação da arte, desde

22 Havelock afirma que "Os admiradores de Platão, normalmente atentos aos mínimos detalhes de seu discurso, quando chegam a um contexto como o mencionado, começam a olhar ao redor à procura de uma porta de emergência e encontram uma que julgam ter sido fornecida pelo seu autor" (HAVELOCK, 1996, p. 21). Não é necessário, todavia, procurar uma saída de emergência para a visão de Platão, pois, como explicado, a percepção de Platão acerca da poesia é diferente da percepção da personagem Sócrates ao longo do diálogo. 
que a polis esteja formada para entendê-la a partir de seu caráter estético e não religioso.

\section{A expulsão de Adão e Eva do paraíso}

Abordemos, nesta seção, a problemática do conhecimento no Paraíso do Gênesis, além das leis que o regem. O Gênesis, o primeiro livro da Torá ${ }^{3}$ judaica, será o foco para nossas considerações, especificamente seus três primeiros capítulos, considerando também a cultura cristã, que o adotou no Antigo Testamento.

O leitor poderá observar que os versículos possuem uma linha de raciocínio lógica, cada coisa é criada a um tempo certo, segundo as demandas do deus $\mathrm{YHWH}^{24}$. Porém, por vezes, esse raciocínio é quebrado, ocasionando certas dúvidas ao leitor; tais quebras de raciocínio, por mais que não sejam o foco deste artigo, serão evidenciadas e brevemente discutidas. Vamos ao relato!

No princípio, não existia nada, apenas o Ser divino e onisciente. Hegel afirma que o Deus do Gênesis é reconhecido "em espírito e verdade" (HEGEL, 1974, p. 372) e que apenas Ele compreende a si próprio, já que a "razão humana por si mesma é incapaz de alcançar a verdade" (HEGEL, 1974, p. 372). Como um ser onisciente, Deus é o único capaz de ter pleno conhecimento de tudo, inclusive o pleno conhecimento de si.

Tudo que é bom é criado numa sequência lógica que permite a vida na terra. Porém, a primeira quebra de raciocínio produz uma ruptura na periodicidade do relato, pois a criação do homem é apresentada em dois capítulos com diferentes teores: Gênesis 1:26-27 e Gênesis 2:7.

E disse Deus: Façamos o homem à nossa imagem, conforme a nossa semelhança; e domine sobre os peixes do mar, e sobre as aves dos céus, e sobre o gado, e sobre a terra, e sobre todo réptil que se move sobre a terra. E criou Deus o homem à sua imagem; à imagem de Deus o criou; homem e mulher os criou (Gênesis 1:26-27).

23 Também chamado de Pentateuco, é o livro que compõe os cinco primeiros livros da Bíblia: Gênesis, Êxodo, Levítico, Números e Deuteronômio. Torá é um substantivo hebraico e significa "instrução". De acordo com García López, a palavra também significa "lei ou coleção de leis” na Bíblia Hebraica (GARCÍA LÓPEZ, 2004, p. 15).

24 O nome pessoal de Deus é YHWH (יהוה). A palavra é registrada apenas com consoantes e, por isso, não possui a pronúncia definida. A fim de manter a palavra intocada para que não seja usado o nome divino em vão, ela é comumente substituída por "meu senhor", “deus criador" (LEITE, 2020, p. 8-9). No presente artigo, será utilizado a palavra "Deus". 
Já no capítulo seguinte, o tema da criação do homem é retomado de maneira diferente:

E formou o Senhor Deus o homem do pó da terra, e soprou em suas narinas o fôlego da vida; e o homem foi feito alma vivente (Gênesis 2:7).

A sequência da criação dos elementos e dos seres do mundo é apresentada de maneira progressiva, desde a luz até a mulher. Porém, quando a criação do homem é apresentada de maneiras e em momentos diferentes, uma dúvida é gerada acerca da temporalidade, ou seja, como e quando o homem foi criado por Deus. Existem diferenças nos versículos citados, e são elas que buscam dar coerência na periodicidade.

Em Gênesis 1:26-27, a principal informação é quanto à forma do homem, que foi concebido como imagem e semelhança de Deus. O homem foi a primeira mimesis, criado para ser semelhante em imagem, ou seja, a personificação terrena de Deus. As características entre a criatura e seu Criador não são perfeitas, daí a semelhança e não a igualdade. Assim, Adão é terreno, ignorante e incapaz de criar. Nesse versículo, também fica clara a hierarquia do homem em relação aos outros seres do mundo, e não podia ser diferente essa posição, afinal ele foi o único ser criado para ser semelhante a Deus. Por isso, o homem está acima dos outros seres terrestres, mas em inferioridade em relação a seu criador. Artuso explica que a repetição das afirmações em "E criou Deus o homem à sua imagem; à imagem de Deus o criou" (Gênesis 2:7) é utilizada para reforçar a grandeza e dignidade do ser humano, perante os outros seres criados (ARTUSO, 2018, p. 56). Hegel aborda essa questão hierárquica de maneira que vale à pena observar:

A superioridade do homem, imagem de Deus, sobre os animais e sobre as plantas, é implícita e explicitamente admitida; mas, quando se trata de investigar onde é que o elemento divino deve ser descoberto e entrevisto, descurasse precisamente aquilo que constitui a superioridade do homem, e atenta-se apenas nas coisas inferiores (HEGEL, 1974, p. 369).

Em Gênesis 1:26-27, portanto, o foco é a forma física do homem e sua posição hierárquica em relação aos outros seres, e sua posição estática em relação a Deus, enquanto em Gênesis 2:7, o foco é a ação de dar vida ao corpo, ou seja, como Deus fez para criar o homem e torná-lo ser vivente: diz-se da materialidade de seu corpo, o pó da terra, e a ação para incorporar a alma 
vivente, a partir do sopro do fôlego da vida - fica claro que o corpo do homem sem a alma é apenas pó da terra modelado com uma forma específica, e nessa condição que o homem se torna um ser vivente, com alma e motilidade.

Importante ressaltar que Edmund Leach também evidencia a criação do homem em dois versículos diferentes, entretanto o foco do antropólogo é a questão da construção de um mito:

É um traço comum a todos os sistemas mitológicos que todas as estórias importantes se repitam em várias versões diferentes. O Homem é criado no Gênesis $(1,27)$ e é depois criado novamente $(2,7)$. E como se dois primeiros homens não bastassem, ainda temos Noé no cap. 8 (LEACH, 1983, p. 58).

Leach não aborda possíveis interpretações para os versículos citados e discorre sobre a questão como "defeitos acidentais" na história bíblica e que, para as pessoas que creem no mito, "a redundância serve para reassegurar a sua veracidade" (LEACH, 1983, p. 58).

De maneira similar, a criação da mulher também é referida em dois versículos diferentes, no já citado Gênesis 1:27, "E criou Deus o homem à sua imagem; à imagem de Deus o criou; homem e mulher os criou", e em Gênesis 2:22:

E da costela que o Senhor Deus tomou do homem, formou uma mulher, e trouxe-a a Adão (Gênesis 2:22).

No primeiro capítulo, a criação da mulher em conjunto com a criação do homem é apenas uma antecipação do que acontecerá, de fato, em Gênesis 2:22. Neste pequeno versículo do segundo capítulo, pode-se entender como foi possível a criação da mulher, a partir da costela de Adão, logo, a mulher é uma mimesis da primeira mimesis. Consequentemente, a mulher não toma a mesma posição que seu companheiro, mas sim abaixo dele, no cenário terrestre. O motivo da sua existência é explicitado em versículos anteriores:

E disse o Senhor Deus: Não é bom que o homem esteja só; far-lhe-ei uma ajudadora idônea para ele.

Havendo, pois, o Senhor Deus formado da terra todo o animal do campo, e toda a ave dos céus, os trouxe a Adão, para este ver como lhes chamaria; e tudo o que Adão chamou a toda a alma vivente, isso foi o seu nome.

E Adão pôs os nomes a todo o gado, e às aves dos céus, e a todo o animal do campo; mas para o homem não se achava ajudadora idônea (Gênesis 2:18-20). 
As árvores do Éden são criadas logo após o homem. Em Gênesis 2:8-9, temos a descrição do relato:

E plantou o Senhor Deus um jardim no Éden, do lado oriental; e pôs ali o homem que tinha formado.

E o Senhor Deus fez brotar da terra toda a árvore agradável à vista, e boa para comida; e a árvore da vida no meio do jardim, e a árvore do conhecimento do bem e do mal. (Gênesis 2:8-9).

A árvore da vida e a árvore do bem e do mal são os únicos elementos com representação metafísica que situam no plano físico ao alcance dos mortais. Não é descrito, no Gênesis, o motivo de se ter duas árvores com tamanha importância no mundo que está ao alcance do homem e da mulher. Até então, todo ser vivo criado para habitar o mundo estava sujeito à dominação humana. Leach aborda a questão da divisão dos "mundos" e afirma:

Mas essa ordenação lógica das ideias traz uma consequência desconcertante: Deus passa a pertencer ao outro mundo. O "problema" central da religião consiste, portanto, em restaurar alguma espécie de ponte entre o Homem e Deus.

Esse padrão está incorporado à estrutura de qualquer sistema mítico. $\mathrm{O}$ mito primeiro discrimina entre os deuses e os homens para depois ocupar-se com as relações e os intermediários que ligam os homens aos deuses. (LEACH, 1983, p. 59).

Dessa maneira, pode-se entender que as árvores do Paraíso são a ponte capaz de ligar as características divinas e humanas, pois, simbolicamente, as árvores são a representação dos poderes de Deus ao alcance do homem e da mulher. A árvore da vida representa a imortalidade divina, além de representar o poder de dar e tirar a vida dos seres, caso os humanos comessem de seu fruto, poderiam ser iguais a Deus, não mais meros semelhantes ao Criador. A árvore do conhecimento representa a onisciência divina. Porém, Deus não tem o intuito de fazer com que os humanos atravessem a ponte que os separa dos poderes divinos. Assim, em seguida, é introduzida a lei que protege essas árvores:

E tomou o Senhor Deus o homem, e o pôs no jardim do Éden para o lavrar e o guardar.

E ordenou o Senhor Deus ao homem, dizendo: De toda a árvore do jardim comerás livremente, 
Mas da árvore do conhecimento do bem e do mal, dela não comerás; porque no dia em que dela comeres, certamente morrerás (Gênesis 2:15-17).

A história do que acontece é uma das mais conhecidas do Gênesis. De maneira resumida, a serpente convence a mulher de comer o fruto da árvore do conhecimento do bem e do mal. O homem também come do fruto após a mulher o oferecer. Consequentemente, o casal começa a compreender melhor as coisas e percebe que ambos estavam nus. Deus pergunta se eles comeram da árvore do conhecimento do bem e do mal, e o casal explica o que aconteceu:

E Deus disse: Quem te mostrou que estavas nu? Comeste tu da árvore de que te ordenei que não comesses?

Então disse Adão: A mulher que me deste por companheira, ela me deu da árvore, e comi.

E disse o Senhor Deus à mulher: Por que fizeste isto? E disse a mulher: A serpente me enganou, e eu comi (Gênesis 3:1-13).

A postura de Deus diante da situação é de punir todos os seres que descumpriram sua lei: a serpente, Adão e sua mulher (que ainda não possui nome $\left.{ }^{25}\right)$. A mais significativa punição é imposta ao casal, a expulsão do jardim do Éden, o Paraíso em que eles poderiam viver sem nenhuma dificuldade ${ }^{26}$ :

Então disse o Senhor Deus: Eis que o homem é como um de nós, sabendo o bem e o mal; ora, para que não estenda a sua mão, e tome também da árvore da vida, e coma e viva eternamente,

O Senhor Deus, pois, o lançou fora do jardim do Éden, para lavrar a terra de que fora tomado.

E havendo lançado fora o homem, pôs querubins ao oriente do jardim do Éden, e uma espada inflamada que andava ao redor, para guardar o caminho da árvore da vida (Gênesis 3:22-24).

25 O nome de Eva só será atribuído depois das punições impostas ao casal, em Gênesis 3:20.

26 O foco do artigo é discutir a punição da expulsão do casal do jardim do Éden. Porém, Deus impôs inúmeros castigos, dentre eles, amaldiçoou a serpente e fez com que ela rastejasse sobre a terra, determinou que a mulher e a serpente serão inimigas e ferirão uma a outra, multiplicou a dor do parto da mulher e fez com que ela se tornasse submissa ao homem, amaldiçoou a terra que o homem plantaria seu alimento e que teria que trabalhar todos os dias de sua vida para conseguir se alimentar (Gênesis 3:14-19). 
Outra quebra cronológica é apresentada nos versículos 2:17, "Mas da árvore do conhecimento do bem e do mal, dela não comerás; porque no dia em que dela comeres, certamente morrerás", e 3:24, "E havendo lançado fora o homem, pôs querubins ao oriente do jardim do Éden, e uma espada inflamada que andava ao redor, para guardar o caminho da árvore da vida". Primeiramente, no segundo capítulo, somente a árvore do conhecimento do bem e do mal é proibida de maneira clara, a proibição sobre a árvore da vida é conferida apenas implicitamente, já que as duas árvores possuem importância equivalente. A proibição explícita desta última só é feita no terceiro capítulo, depois que Adão e Eva já comeram do fruto da árvore do conhecimento do bem e do mal. Possivelmente, o foco é dado apenas à árvore do conhecimento do bem e do mal na lei do Gênesis 2:17, pois será com ela que virá o desejo pela imortalidade. Dito de outra maneira, uma árvore levaria à outra.

Ao que parece, Deus castiga o homem e a mulher porque o fruto do conhecimento do bem e do mal possibilitou ao casal ser ainda mais semelhante ao seu criador. Reimer discorre sobre a condenação:

O desenlace mais profundo na narrativa mítica é indicado no final com a expulsão do homem e da mulher do jardim. Antes, porém, há ainda a menção de que, com a ação da transgressão das ordens de Deus, o ser humano se tornou sábio como o próprio Deus, conhecedor do bem e do mal (v. 22). Por isso, é lançado fora do jardim para "lavrar a terra de que fora formado", isto é, para se dedicar à sua função principal de cultivador da terra. Com este desenlace, há uma condenação da busca da sabedoria. $\mathrm{Na}$ ótica de quem formula o enredo mítico imaginário, a autonomia e o conhecimento não deveriam ser 'democratizados', mas restritos a Deus ou a quem se expressa por ele (REIMER, 2009, p. 101).

A hipótese é reforçada no momento em que Deus guarda a árvore da vida, afinal, depois do crime, teme que Adão e Eva possam desfrutar do poder sobre a vida, assim como Ele.

As consequências da expulsão de Adão e Eva são:

a semelhança do homem a Deus, a primeira mímesis divina, é limitada a uma hierarquia bem definida, em que ao homem é proibido o conhecimento sobre o poder da vida e sobre o bem e o mal;

a semelhança da mulher ao homem, a segunda mímesis divina, é ainda mais limitada, já que, nela, o poder divino parece ter menos efeito, uma vez que 
é Eva que leva Adão a comer do fruto proibido; por ser menos dedicada à ignorância, a mulher representa o perigo à ordem do Paraíso - disto viria a justificativa do comando do homem sobre a mulher;

a implícita defesa de que o conhecimento (da vida, do bem e do mal) deve ser proibido ao ser humano, pois, em suas mãos, tal conhecimento tornarse-ia uma ameaça à ordem da pureza, determinada pelo distanciamento do conhecimento;

a implícita ideia de que a ignorância é mais apreciada que o conhecimento no Paraíso, e, para proteger o ser humano, é melhor esconder-lhe o conhecimento, proibindo-lhe o alcance.

Importante ressaltar que, ao comerem do fruto, o casal se liberta da ignorância. Caso não comesse, continuaria ingênuo, puro e poderia ser enganado por qualquer um. Prova disso é que a serpente assim o fez, um animal que foi criado para ser hierarquicamente inferior ao homem. Mas, na contradição interna, pela ignorância do casal, consegue ludibriá-lo. Reimer pondera sobre como a serpente passa a ser um símbolo negativo a partir do Gênesis:

A serpente conversa com a mulher sobre coisas que exigem sabedoria e discernimento. Por exemplo, a conversa gira sobre como saber o que é bom para comer e o que pode ajudar no desenvolvimento intelectual. Na conversa predomina o léxico relativo ao que é 'bom' e ao que é 'mau', o que é típico das tradições sapienciais do antigo Israel. Trava-se um verdadeiro diálogo entre a serpente e a mulher. Neste diálogo, as ordens de Deus ao casal originário são repassadas criticamente e relativizadas. (...) E justamente a serpente é afirmada como a causadora dessa transgressão. Assim, na narrativa de Gênesis 3, a serpente como símbolo perdeu sua polissemia intrínseca e opera na "isotopia do negativo" (REIMER, 2009, p. 99).

O conhecimento do bem e do mal conferido à serpente foi capaz de ludibriar a mulher e o homem, mesmo estes tendo poder sobre todos os outros seres do Paraíso.

Ao punir Adão e Eva com um castigo tão severo, é tirada a importância da (auto)emancipação do ser humano, e a ignorância passa a ser percebida como algo "bom" e indispensável para o bem da coletividade no Paraíso. Edmund Leach enfatiza outro ponto essencial do (auto)conhecimento de Adão e Eva:

Adão e Eva comem o fruto proibido e tornam-se conscientes da diferença sexual. A morte torna-se inevitável (3, 3-8), mas, pela primeira vez, a gravidez 
e a reprodução tornam-se possíveis. Eva não engravida senão depois de ter sido expulsa do Paraíso (4,1) (LEACH, 1983, p. 65).

Apenas com a ameaça da morte, foi possível dar hereditariedade à vida humana. A dor do parto também é intensificada como punição para a vida que não vem diretamente de Deus, um tipo de mímesis independente, que se dá em três graus de inferioridade: $1^{\circ}$, Adão; $2^{\circ}$, Eva; $3^{\circ}$, seus descendentes.

A partir de então, o ser humano irá procurar um (auto)conhecimento, para aprender a lidar com os problemas da vida fora do Paraíso, já que o criador não o capacitou quanto a tais problemas, deixando a vida mais suscetível a erros. Mas esta foi uma escolha humana.

Hegel aborda as diferenças da filosofia e da religião em sua Introdução da bistória da filosofia:

A religião e mais precisamente os teólogos ignoram a filosofia só para não serem contraditórios na sua maneira arbitrária de raciocinar. Parece, portanto, que a religião pretende que o homem se abstenha de pensar nos objetos universais e da filosofia, que afinal se reduzem a [sic] sabedoria humana, a operações humanas, contrapondo a razão humana à razão divina. Assim, como é costume, distingue-se o ensinamento divino e a lei do mero saber humano e da invenção, compreendendo nesta expressão tudo quanto procede da consciência, da inteligência ou da vontade do homem, em antítese com o conhecimento de Deus, com as coisas que participam do divino, mercê da divina revelação. (...) Assim, tudo quanto é exterior e acidental é exaltado como obra de Deus, e a parte substancial, que lança as raízes na vontade e na consciência, é considerada obra do homem (HEGEL, 1974, p. 368-369).

De certa maneira, pode-se dizer que essa aversão à filosofia, em nossas influências ocidentais, tem seu princípio no mito de Adão e Eva, que desobedeceram à razão divina e tornaram evidente a razão humana, e, assim, pagaram a expulsão do Paraíso por essa escolha.

Ao longo da narrativa, surgem questões que não são explicadas, por exemplo a não instrução do homem quanto aos males do mundo: o mal existe no mundo criado por Deus, porém o mal é escondido e dominado pela divindade, e o homem é dotado de ignorância para sua própria proteção, como se, por não conhecer o mal, o homem não o pudesse cometer, mantendo, assim, a mais pura perfeição do Paraíso. O Estado, nesse sentido, é representado por Deus, que não educa de dentro para fora seus cidadãos, mas antes lhes impõe de fora para dentro regras bem específicas. Dessa 
maneira, o ser humano é responsabilidade de Deus, e sua piora como ser está na mesma dimensão da quebra de sua ignorância. Em outras palavras, a busca pelo conhecimento é a causa fundamental de sua expulsão.

\section{Alguns confrontos}

Existem similaridades e diferenças nas narrativas apresentadas. Antes de tudo, é necessário traçar os paralelos, mesmo que pareçam triviais: na polis platônica, o governante é iniciando em filosofia, que, inicialmente, age como um tirano, mas que, posteriormente, age como um filósofo, e suas leis, respectivamente, são formativas de fora para dentro e educativa de dentro para fora; no Paraíso bíblico, o governante é um ser divino e onisciente, a sociedade é composta por apenas dois seres que são hierarquicamente diferentes (o homem é um ser superior à mulher), as leis são punitivas e foram criadas para garantir a ignorância do homem e da mulher.

Na República, considerando o drama da personagem Sócrates, a postura filosófica refletida e alcançada por ele é a de que o Estado tem o dever de auxiliar seus cidadãos a buscarem elevar suas psychai. Assim, apenas o indivíduo que manipular a poesia (a arte por assim dizer), a fim de buscar manter a ignorância dos indivíduos no interior da polis, deveria ser punido com a expulsão. Nesse sentido, pretende-se, ao final do diálogo, expulsar a ignorância, não o grande artista.

Por outro lado, no Gênesis, a postura filosófica pelo conhecimento é negada aos cidadãos do Paraíso, e Deus, que representa o governo do Estado, protege seus cidadãos contra o mal por meio da imposição de regras que os coloca em um patamar de submissão e de ignorância. Nesse sentido, a desobediência de tais regras leva à sua expulsão.

Logo, na polis platônica, a lei vigente é baseada na educação dos indivíduos, para que não sejam manipulados por nenhum tipo de governo ou governante. No Gênesis, a lei vigente é baseada na ignorância, para que os cidadãos se mantenham obedientes ao governante divino.

As poesias homéricas são apresentadas, em um primeiro momento da República, como "verdades" religiosas, cujos ignorantes creem e, baseado nelas, são manipulados. É importante ressaltar que o artista, nesse caso Homero, não tem o intuito de ludibriar a polis, mas de relatar alguns mythoi que tocam a psyche humana. Sua leitura como um texto religioso é feita pela tradição, reforçada pelo Estado e praticada pelos indivíduos, por não terem uma educação estética. 
De acordo com Nichols, O Antigo Testamento teria sido escrito, segundo a tradição judaico-cristã, sob inspiração de Deus ${ }^{27}$. García López explica que, por séculos, a tradição judaico-cristã acreditou que Moisés era o autor da Torá. A partir do Iluminismo, as críticas literárias alertaram sobre "as repetições, as tensões, as mudanças frequentes de estilo, etc" e concluíram que a Torá é uma obra de vários autores (GARCÍA LÓPEZ, 2004, p. 33) ${ }^{28}$. Muitos livros judaicos como o Gênesis não têm autoria declarada, e, por esse motivo, sugerimos seu caráter religioso, como se tivessem sido escritos por Deus (ou pelo menos inspirados por ele), reforçando a ideia de que eles são exemplos de verdades que devem ser seguidas.

O conhecimento, para ambas as narrativas, possui a mesma definição em termos gerais, a compreensão da verdade. Na República, a compreensão da verdade é alcançada pelo indivíduo de dentro para fora, ou seja, as leis impostas e punitivas não auxiliam o conhecimento; assim, os mythoi, se interpretados como imagem metafórica a partir de seu valor estético, podem auxiliar a tocar as psychai dos indivíduos e proporcionar (auto)conhecimento. No Gênesis, a verdade é a palavra inquestionável de Deus, e a razão humana é apresentada como incapaz de compreender a verdade; a ignorância, dessa maneira, é mais apreciada do que o conhecimento, porque é ela que salvaguardará a integridade do ser humano.

Na República, o conhecimento passa por dois momentos diferentes: o primeiro momento é quando o mythos é percebido como um objeto religioso, o segundo momento é quando o mythos supera a percepção religiosa e se consolida como uma obra de arte. Nesse contexto imaginado por Sócrates, a compreensão dos mythoi pelos indivíduos da polis é diretamente ligada ao nível de conhecimento das psychai. Quando estas não foram formadas e orientadas, os mythoi possuem um caráter religioso. Essa característica é reforçada quando o Estado se apropria dos mythoi para manipular a formação da polis e não alerta a sociedade sobre seu real desígnio. Em contrapartida, quando os indivíduos da polis elevam suas psychai com o auxílio da Filosofia, a arte supera a percepção religiosa indevida do mythos. Em síntese, a Filosofia auxilia a elevação das psychai dos indivíduos, consequentemente, os mythoi são compreendidos pelo seu real desígnio e também auxiliam na elevação contínua das psychai.

No Gênesis, o conhecimento também passa por dois momentos: o

$27 \quad$ Acerca desse tema, cf. NICHOLS, 2009, p. 1.

28 Acerca desse tema, cf. GARCÍA LÓPEZ, 2004, p. 32-33. 
primeiro é aquele em que apenas Deus detém o conhecimento, impondo sua palavra como verdade a ser seguida religiosamente; o segundo é aquele em que os cidadãos profanam a palavra divina, quebrando, assim, sua lei. Nesse sentido, o nível de conhecimento dos cidadãos está ligado diretamente ao nível de obediência que têm em relação a Deus. Enquanto são obedientes, eles são ignorantes e vivem no Paraíso, mas, quando desobedecem, adquirem conhecimento e são expulsos.

As duas narrativas também abordam sobre a mimesis. Na República, a temática é aprofundada no livro décimo, em que Sócrates explica a Glauco que a mímesis deve ser renegada pela sociedade, pois são objetos desprovidos de realidade e podem enganar os ingênuos e ignorantes. Por outro lado, na Bíblia, a mímesis ${ }^{29}$ é tratada de maneira mais positiva. O homem tem a honra de ter sido feito com a imagem e semelhança de Deus, logo, está hierarquicamente acima dos outros seres criados. A mulher não é criada com a imagem e semelhança de Deus, pois foi criada a partir de uma fração do homem, logo a mulher é uma mimesis da mimesis, dessa maneira, a mulher é subordinada ao homem de acordo com o Gênesis.

$\mathrm{Na}$ República, Sócrates possui duas percepções acerca do artista e da poesia. O diálogo apresenta dramaticamente essa mudança de postura, em que Sócrates reavalia seu posicionamento a partir da dialética. No primeiro momento, numa postura tirânica, Sócrates deixa claro que o conhecimento deve ser apreendido apenas pelos governantes, a sociedade permaneceria, em parte, na ignorância, pois o Estado é quem decidiria o que deve ou não ser exposto. Consequentemente, o Estado seria um manipulador da verdade. Num segundo momento, Sócrates repensa sua estratégia e assume uma postura real de filósofo. A educação deve ser oportunizada a todos, para que a sociedade não seja manipulada por ninguém, nem mesmo pelo Estado. É possível perceber que Platão utiliza a personagem Sócrates para exemplificar como um indivíduo busca o melhoramento da psyche e se torna um filósofo.

No Gênesis, Deus possui uma postura tirânica ao condicionar o homem e a mulher à ignorância e proibi-los de obter o conhecimento. Dessa maneira, o único que deve ser detentor do conhecimento é Deus, ser onisciente. O homem e a mulher são castigados com dor e sofrimento, além da expulsão do Paraíso perfeito, quando se (auto)libertam da ignorância.

29 O termo "mímesis" não é referido na Bíblia. Utiliza-se este termo, no artigo, a partir do contexto que Deus criou o homem com uma forma semelhante à Sua imagem. 


\section{Luciano Coutinho}

Caroline Albergaria

Assim, enquanto, na República, o bem está relacionado à dialética e ao melhoramento da psyche, no Gênesis, o bem está ligado à ignorância do indivíduo.

\section{Referências}

ARTUSO, V. Pentateuco e livros históricos. Curitiba: InterSaberes, 2018. (Série Princípios de Teologia Católica).

BÍBLIA. Bíblia: Almeida Corrigida Revisada e Fiel. Disponível em: <https://www.bibliaonline.com.br/acf/gn/1>. Acesso em: 16 mar. 2020.

CORNELLI, G. "Aquele que ama o mito é, de alguma forma, filósofo: Algumas considerações sobre a necessidade do mito para a filosofia". In: Phoinix, v. 9, n. 1, p. 110-127, 2003. Disponível em: <http://phoinix.historia.ufrj.br/media/uploads/artigos/7_-_Aquele_que_ ama_o_mito_e_de_alguma_forma_filosofo_-_Gabrielle_Corneli.pdf>. Acesso em: 30 out. 2020.

. "Platão aprendiz do teatro: a construção dramática da filosofia política de Platão". In: VIS (UnB), v. 9, n. 2, p.75-84, 2010. Disponível em: <https://periodicos.unb.br/index. $\mathrm{php} /$ revistavis/issue/view/2000/423>. Acesso em: 30 out. 2020.

COUTINHO, L. "A expulsão da arte-verdade na República de Platão ou a problemática da percepção psíquica em torno dos mythol”. In: RES - Revista de Estética e Semiótica, v. 7, n. 2, p. 113-128, 2017a. Disponível em: <https://periodicos.unb.br/index.php/esteticaesemiotica/ article/view/12234/10728>. Acesso em: 15 jul. 2020.

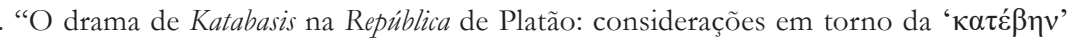
(R. 1, 327a1)” In: XAVIER, D. G., COUTINHO, L., CURADO, M. (Orgs.). Filosofia Antiga: reflexões da vida cósmica e da vida social. Brasília: Tanto Mar Editores, p. 113-136, $2017 \mathrm{~b}$.

"A vida justa e a invisibilidade do filósofo na República de Platão". In: Educação

e Filosofia, v. 32, n. 65, p. 845-865, 2018. Disponível em: < http://www.seer.ufu.br/index. php/EducacaoFilosofia/article/view/37773/26027>. Acesso em: 10 set. 2020.

Katabasis e psyche em Platão. 2015. 306f. Tese (Doutorado em Estudos Clássicos) - Faculdade de Letras, Universidade de Coimbra. Disponível em: <https://eg.uc. pt/bitstream/10316/28391/1/Katabasis $\% 20 \mathrm{e} \% 20$ Psyche $\% 20 \mathrm{em} \% 20$ Plat $\%$ c3\%a3o.pdf $>$. Acesso em: 10 jan. 2020.

CURADO, M. "A eugenia platónica: um ensaio prudencial” In: XAVIER, D. G., COUTINHO, L., CURADO, M. (Orgs.). Filosofia Antiga: reflexões da vida cósmica e da vida social. Brasília: Tanto Mar Editores, p. 187-246, 2017.

GARCÍA LÓPEZ, F. O Pentateuco. São Paulo: Ave Maria, 2004.

HAVELOCK, E. Prefácio a Platão. Trad. Enid Abreu Dobránszky. São Paulo: Papirus, 1996.

HEGEL, G. W. F. A fenomenologia do espírito; Estética: a idéia e o ideal; Estética: o belo artístico e o ideal; Introdução à história da filosofia. Trad. Antônio Pinto de Carvalho. São Paulo: Abril Cultural, 1974. (Coleção Os Pensadores; 30). 
HOMERO. Ilíada. Trad. Frederico Lourenço. 1 ed. São Paulo: Penguin Classics e Companhia das Letras, 2013.

LEACH, E. "O Gênesis enquanto um mito". In: DaMATTA, R. (Org.). Edmund Leach Antropologia. São Paulo: Ática, p. 57-69, 1983.

LEITE, A. B. C. D. "A forma da eternidade". In: Archai, n. 28, p. 1-29, 2020. Disponível em: <https://impactum-journals.uc.pt/archai/article/view/_28_1/6165>. Acesso em: 30 out. 2020.

MUNIZ, F. "Platão contra a Arte". In: HADDOCK-LOBO, R. (Org.). Os Filósofos e a Arte. Rio de Janeiro: Rocco, p. 15-42, 2010. Disponível em: <https://www.academia. edu/33971757/Plat\%C3\%A3o_contra_a_arte>. Acesso em: 25 jun. 2020.

NICHOLS, L. D. Big Picture of the Bible: New Testament. Enumclaw: WinePress Publishing, 2009.

PLATÃO. A República. Trad. Maria Helena de Rocha Pereira. 9 ed. Lisboa: Fundação Calouste Gulbenkian, 2001.

REIMER, H. "Forma e Lugar de Genesis 3 na História da Religião Hebraica". In: Fragmentos de Cultura, v. 19, n. 1/2, p. 91-109, 2009. Disponível em: <http://seer.pucgoias.edu.br/index. $\mathrm{php} /$ fragmentos/article/view/1007/708>. Acesso em: 30 out. 2020.

VEGETTI, M. “Megiston mathema: l'idea del 'buono' e le sue funzioni”. In PLATÃO. La Repubblica. v. 5. Trad. Mario Vegetti. Napoli: Bibliopolis, p. 253-286, 2003.

Submetido em: 14-11-2020

Aceito em: 21-1-2022 